\title{
Evaluation on Information Disclosure of Rural Commercial Banks' Off-Balance Sheet Activities
}

\author{
Dongmei Wang ${ }^{1, a}$ and Shang Dan ${ }^{2, b}$
}

\author{
${ }^{I}$ No.7366, Erhuan East Road, Lixia District, Jinan, Shandong University of Finance and Economics, PRC \\ ${ }^{2}$ Shandong Jining Rural Commercial Bank, Jining, Shandong, PRC \\ nancywdm@sina.com, ${ }^{b}$ nxshangdanl@126.com
}

\begin{abstract}
It is an effective risk control and prevention method to constantly improve the information disclosure of rural commercial banks'off-balance sheet activities. An objective evaluation is the basis. Based on its qualitative characteristics, the paper structures evaluation index system which includes 4 level-1 indexes of timeliness, authenticity, integrity and importance, and 14 level-2 indexes, using for twelve Rural Commercial Banks from 2014 to 2016. The results show that they features different level. Some ranking ahead and large scale banks disclose relatively adequate information. In terms of elements, rural commercial banks differ greatly from each other in their timeliness. The authenticity index is relatively better disclosed. And the integrity and importance indexes need to be further improved. In particular, the off-balance sheet activities of rural commercial banks should make progress in business category, specific operation and risk disclosure.
\end{abstract}

Keywords: Rural Commercial Banks, off-balance sheet activities, information disclosure

\section{INTRODUCTION: BACKGROUND AND SIGNIFICANCE}

With the continuous progress of interest rate marketization, the net interest margin of banks is narrowing. The profits brought by traditional business are decreasing, and banks urgently need to find new profit growth points.Off-balance sheet business has the characteristics of transferring and diversifying risks, increasing profitability and improving financial structure. Therefore, under the self-discipline and incentive of profit-seeking, the off-balance-sheet business of commercial banks develops rapidly, showing the alternative utility of credit. The future is bound to become the pillar of commercial bank competition.However, it also will bring huge profits to the bank, but at the same time, it will also bring huge risks to the bank due to its high leverage and low transparency.Compared with large commercial banks, rural commercial banks have strong arbitrariness in business operation, weak awareness of risk prevention, imperfect rules and regulations, and higher risk of off-balance sheet business.In the report of the 19th National Congress of the Communist Party of China, it is proposed to "keep the bottom line of non-systemic financial risk", and prevent the risk of off-balance sheet activities is also an important element of this requirement.As an effective means of risk prevention and control, it is of great significance to improve the disclosure of external business information of rural commercial banks and to improve the quality of external information disclosure [1], and to accept the supervision of the use of external information.

\section{CONCEPT DEFINITION}

\subsection{Off-Balance Sheet Activities of Rural Commercial Banks}

The off-balance-sheet activities mainly refers to the definition of the Basle Committee, that is, under certain conditions, the business that constitutes the bank's contingent assets or liabilities can be converted into on balance sheet assets or liabilities, and it plays a certain role in the change of current profit and loss and working capital.This business generally does not occupy bank funds.once the conditions are met or there is a risk, it becomes an asset liability business[2]., It can be divided into financial service business or contingency business according to the business risk.It can be divided into settlement business, management business, service business, guarantee business, financing business and derivative financial instrument business according to the business varieties,. The risks of off balance sheet business include credit risk, market risk, liquidity risk and operational risk[3].

\subsection{Information Disclosure of Off-Balance Sheet Activities}

\subsubsection{Business Varieties and Specific Operation}

In order to facilitate users of financial statements to fully understand the attributes of off-balance sheet business, rural commercial banks should disclose the varieties and specific operation modes of off-balance sheet business.Taking the entrusted investment business as an example, the specific operational information that should be disclosed should cover the assets of the business trustee in accordance with the 
instructions of the entrusting bank in the name of the trustee, such as bank deposits, bill assets, trust plans, directional asset management plans, etc.

\subsubsection{Scale and Amount Information}

For contingent matters, the rural commercial bank shall disclose the amount of contingencies, including the issuance of letters of credit, loan commitments, bank acceptance bills, transfer and discount, letters of guarantee and asset sales items with resource.Derivative financial products shall be classified and reflected according to the term of the contract,including the market value of derivative financial products at the end of the accounting period, the contract price, the profit and loss calculated according to the market price at the end of the accounting period etc.

\subsubsection{Description of Risk and Risk Management}

Rural commercial banks should disclose the measurement techniques and means of various risks, the methods of off-balance sheet activities risk management and risk mitigation measures. If there are many methods of risk management, the method of obtaining the most relevant and effective information should be explained.

\subsubsection{Income Information}

It mainly includes off-balance sheet activities income and specific structure, which can reflect the development prospect and business contribution of off-balance sheet

Table 1 Requirements of Different Institutions for Information Disclosure Quality

\begin{tabular}{l|l|l}
\hline institution & Related documents & Information quality characteristics \\
\hline $\begin{array}{l}\text { Basel } \\
\text { Committee }\end{array}$ & Enhance bank transparency & $\begin{array}{l}\text { Comprehensiveness, relevance and timeliness, } \\
\text { authenticity, comparability and importance }\end{array}$ \\
\hline CBRC & $\begin{array}{l}\text { Interim Measures for disclosure of } \\
\text { information content of commercial banks }\end{array}$ & Authenticity, integrity, accuracy and comparability \\
\hline CSRC & $\begin{array}{l}\text { Rules for information disclosure of public } \\
\text { securities companies }\end{array}$ & True, accurate, complete, fair and timely \\
\hline
\end{tabular}

Based on the above table, we design a questionnaire to seek the opinions of experts and scholars in order to extract the level-1 indexes of this paper. In order to ensure the objectivity and impartiality, the respondents have both front-line staff business;off-balance-sheet business asset price level,off-balance sheet activities fair value change amount, cumulative change amount caused by risk and market change, credit derivatives fair value change amount in current period, etc.

\section{EVALUATION ON INFORMATION DISCLOSURE OF RURAL COMMERCIAL BANKS' OFF-BALANCE SHEET ACTIVITIES}

\subsection{Information Disclosure Evaluation Index System}

Based on the quality characteristics of the off-balance sheet information disclosure of Rural Commercial Bank, Determine the level-1 indexes and weight through interview, questionnaire, expert scoring and other methods. Refine the level-1 indexes into specific indicators that can be evaluated through the surface content of information disclosure. Finally, the specific items of level-2 indexes are determined by questionnaire survey and scoring method.

\subsubsection{Establishment and Weight of Level-1 Indexes}

Table 1 shows the requirements of different institutions on the quality characteristics of information disclosure of commercial banks. and academic researchers. The questionnaire is distributed by e-mail and on-the-spot. The distribution and recovery of the questionnaire are shown in Table 2. 
Table 2 Questionnaire

\begin{tabular}{l|l|l|l|l}
\hline \multicolumn{1}{c|}{ Respondents } & \multicolumn{1}{|c|}{ Qualification of respondents } & Number & $\begin{array}{l}\text { Number } \\
\text { valid copies }\end{array}$ & $\begin{array}{l}\text { Rate } \\
\text { recovery }\end{array}$ \\
\hline University Teachers & $\begin{array}{l}\text { Deputy senior or above, which has } \\
\text { published important papers and presided } \\
\text { provincial projects }\end{array}$ & 21 & 15 & $71.43 \%$ \\
\hline $\begin{array}{l}\text { Members of the board of } \\
\text { directors, board of supervisors } \\
\text { and senior management }\end{array}$ & $\begin{array}{l}\text { Members of the board of directors and } \\
\text { supervisors and senior managers }\end{array}$ & 47 & 36 & $76.60 \%$ \\
\hline $\begin{array}{l}\text { Legal representative of natural } \\
\text { or legal shareholders }\end{array}$ & $\begin{array}{l}\text { Select some shareholders of rural } \\
\text { commercial banks }\end{array}$ & 112 & 81 & $72.32 \%$ \\
\hline $\begin{array}{l}\text { General staff of rural } \\
\text { commercial banks }\end{array}$ & $\begin{array}{l}\text { Take out employees of rural commercial } \\
\text { banks }\end{array}$ & 206 & 162 & $78.64 \%$ \\
\hline $\begin{array}{l}\text { Staff of CBRC and people's } \\
\text { Bank of China }\end{array}$ & $\begin{array}{l}\text { Staff with bank management experience } \\
\text { in banking regulatory bureau, people's } \\
\text { Bank of China and other departments }\end{array}$ & 17 & 10 & $58.82 \%$ \\
\hline A
\end{tabular}

A total of 403 questionnaires were sent out, and 304 invalid questionnaires were eliminated.

According to the results of the questionnaire survey, we finally focus on the timeliness, integrity, authenticity and importance of the level-1 indexes of quality characteristics. For the setting of the level-1 indexes indicator weight, we require the respondents to use the percentage system to score, the sum of the four level-1 indexes is 100 points, and then calculate the mean according to the scoring situation. After receiving the questionnaire, the scores were summarized, and the average scores of timeliness, integrity, authenticity and importance were 10 points, 20 points, 10 points and 60 points respectively.

\subsubsection{Establishment of Level-2 Indexes}

In determining the level-2 indexes, we first get a series of indicators through large-scale interviews with information users and experts. Using the method of questionnaire survey, the respondents are required to score and screen according to the 6-point stratified scoring method ( 1 indicates that it is not important at all, 6 indicates that it is important). After summarizing the questionnaire, the average score of each level-2 index is calculated, and each level-2 index is sorted according to the level of the average score. The index with an average score of more than 3.5 becomes the final level-2 indexes.

In this way, we extract 4 level-1 indexes and select 14 level-2 indexes according to the results of the questionnaire survey. See Table 3 for the evaluation system of off-balance-sheet information disclosure of rural commercial banks. 
Table 3 Quality Evaluation System of Off-Balance-Sheet Information Disclosure

\begin{tabular}{|c|c|c|c|}
\hline Weights & primary & Indicators(secondary) & $\begin{array}{l}\text { Score and assignment description of } \\
\text { level- } 2 \text { indexes }\end{array}$ \\
\hline $10 \%$ & Timeliness A1 & $\begin{array}{l}\text { Whether the disclosure date of off-balance sheet } \\
\text { information is within the specified time range A11 }\end{array}$ & $\begin{array}{l}\text { According to the degree of disclosure } \\
\text { concentration, the value is assigned } \\
\text { by equal partition method, and the } \\
\text { earliest is } 5 \text {, others are } 4,3,2,1 \text { in } \\
\text { turn. }\end{array}$ \\
\hline \multirow{4}{*}{$20 \%$} & \multirow{4}{*}{ AuthenticityA2 } & Disclosure of audit report A21 & $\begin{array}{l}\text { Not disclosed }=1 \text {; disclosed but not } \\
\text { detailed }=3 \text {; disclosed and detailed }=5\end{array}$ \\
\hline & & $\begin{array}{l}\text { Whether to change accounting firm compared with } \\
\text { the previous year A } 22\end{array}$ & No change $=5 ;$ change $=1$ \\
\hline & & $\begin{array}{l}\text { Whether the off-balance sheet activities has been } \\
\text { condemned or punished by departments for } 3 \\
\text { consecutive years A23 }\end{array}$ & $\begin{array}{l}\text { Not condemned }=5 \\
\text { condemned }=3 \\
\text { condemned and punished }=1\end{array}$ \\
\hline & & Type of audit report A24 & $\begin{array}{l}\text { Unqualified } \quad \text { opinion } \\
\text { explanation) }=5 \text {; unqualified } \\
\text { opinion }(\text { with } \\
\text { explanation })=4 ; \text { qualified opinion } \\
=3 ; \text { rejected opinion }=2 ; \text { Negative } \\
\text { opinion }=1\end{array}$ \\
\hline \multirow{3}{*}{$10 \%$} & \multirow{3}{*}{ CompletenessA 3} & $\begin{array}{l}\text { Whether to introduce the definition of off-balance } \\
\text { sheet activities A31 }\end{array}$ & \multirow{3}{*}{$\begin{array}{l}\text { Not disclosed }=1 \text {; disclosed but not } \\
\text { detailed }=3 \text {; disclosed and detailed }=5\end{array}$} \\
\hline & & $\begin{array}{l}\text { Whether to disclose activities varieties and specific } \\
\text { operation A32 }\end{array}$ & \\
\hline & & $\begin{array}{l}\text { Whether to introduce responsibilities and authorities } \\
\text { of management organizations of off-balance sheet } \\
\text { activities A33 }\end{array}$ & \\
\hline \multirow{6}{*}{$60 \%$} & \multirow{6}{*}{ Importance A4 } & $\begin{array}{l}\text { Whether to disclose the off-balance sheet activities } \\
\text { scale and amount A41 }\end{array}$ & \multirow{6}{*}{$\begin{array}{l}\text { Not disclosed }=1 \text {; disclosed but not } \\
\text { detailed }=3 \text {; disclosed and detailed } \\
=5\end{array}$} \\
\hline & & $\begin{array}{l}\text { Whether to disclose the income of off-balance sheet } \\
\text { activities A42 }\end{array}$ & \\
\hline & & Whether to disclose credit risk A43 & \\
\hline & & Whether to disclose market risk A44 & \\
\hline & & Whether to disclose liquidity risk A45 & \\
\hline & & Whether to disclose operational risk A46 & \\
\hline
\end{tabular}

\subsection{Evaluation on Information Disclosure of Rural Commercial Banks'Off-Balance Sheet Activities}

In this paper, 19 rural business behavior research objects in the top 100 bank rankings released by China Banking Association in November 2017 are selected (the 2017 business situation is not ranked in 2018, so the 2017 ranking is selected for analysis). After removing the data discontinuous samples from 2014-2016, the final research object of this paper is a total of 12 rural commercial banks, namely CQ, SH, BJ, GZ, CD, DG, TJ, WH, JN, CS, DL, JY. These rural commercial banks have been listed or are going to be listed, which are under the supervision of the regulatory agencies and the investment public. The content of accounting information disclosure is relatively sufficient, which is convenient for horizontal comparison. At the same time, their assets and liabilities scale are large, which has strong representation in China's rural commercial banks.

According to table 3 , the level of off-balance sheet information disclosure of 12 rural commercial banks was scored, and the results are shown in Table 4. 
Table 4 Score of Off-Balance Sheet Information Disclosure of 12 Rural Commercial Banks

\begin{tabular}{|c|c|c|c|c|c|}
\hline Bank name & Timeliness A1 & AuthenticityA2 & CompletenessA 3 & $\begin{array}{c}\text { Importance } \\
\text { A4 }\end{array}$ & Score \\
\hline CQ & 5 & 20 & 9 & 30 & 23.4 \\
\hline $\mathrm{SH}$ & 4 & 20 & 9 & 30 & 23.3 \\
\hline $\mathrm{BJ}$ & 4 & 20 & 9 & 30 & 23.3 \\
\hline GZ & 4 & 20 & 13 & 28 & 22.5 \\
\hline $\mathrm{CD}$ & 4 & 20 & 13 & 28 & 22.5 \\
\hline DG & 4 & 18 & 5 & 6 & 8.1 \\
\hline $\mathrm{TJ}$ & 4 & 20 & 11 & 20 & 17.5 \\
\hline WH & 1 & 18 & 3 & 6 & 7.6 \\
\hline $\mathrm{JN}$ & 3 & 20 & 9 & 16 & 14.8 \\
\hline $\mathrm{CS}$ & 1 & 18 & 3 & 16 & 13.6 \\
\hline DL & 1 & 18 & 3 & 6 & 7.6 \\
\hline JY & 1 & 20 & 9 & 24 & 19.4 \\
\hline
\end{tabular}

Attachment: The original data is derived from the annual report disclosed on the official website of rural commercial banks on 2014-2017, and the final score is obtained based on manual summary.

\subsubsection{Timely Disclosure}

Most rural commercial banks disclose information in a timely manner and within four months after the end of the fiscal year in accordance with the requirements of the Interim Measures for information disclosure of commercial banks on the frequency of information disclosure. There are 8 rural commercial banks that disclose information within four months after the end of the fiscal year, namely $\mathrm{CQ}, \mathrm{SH}, \mathrm{BJ}$, GZ, CD, DG, TJ and JN. The disclosure of the other four rural commercial banks is relatively backward, namely $\mathrm{WH}, \mathrm{CS}$, DL and JY. For example, for sample WH, the disclosure time of 2014-2016 annual report is respectively April 11, 2015, May 17, 2016 and may 17, 2017. The information disclosure in 2015 and 2016 did not meet the relevant requirements of the Interim Measures for information disclosure of commercial banks.

\subsubsection{Disclosure of Authenticity}

12 rural commercial banks have disclosed the audit report of the current year; they have not changed the accounting firm; they have not been condemned or punished by CBRC, CSRC or audit bureau due to their off balance sheet business within three years; the accounting firm has issued an unqualified audit report (no explanation).

\subsubsection{Integrity Disclosure}

First,off-balance sheet activities definition.There are only four banks that disclose the definition of off-balance-sheet business, GZ,CD,TJ and JN. In the notes to the financial statements, the above-mentioned rural commercial bank gives a literal description of the definitions of various off balance sheet businesses carried out by the bank.
Second, the variety and operation of off-balance sheet business. This paper makes a detailed textual description of the varieties and connotations of off-balance sheet business, and makes a textual explanation of the specific operation and investment of the business. There are five banks with the most adequate disclosure, which are $\mathrm{CQ}, \mathrm{SH}, \mathrm{BJ}, \mathrm{GZ}$ and $\mathrm{CD}$. Taking SH's disclosure of financial management business as an example,the bank introduced the wealth management business in detail, considering whether there is control over the wealth management products, and based on the decision-making scope of the bank as the asset manager and the holder of the wealth management products. Factors such as the power, the remuneration for providing management services, and the exposure to variable income risk are used to judge whether the bank is the main responsible person or agent of the wealth management product manager.Wealth management products are mainly invested in brokerage asset management plans, trust plans, etc. The underlying assets mainly include standardized debt assets with a rating above $\mathrm{A}+$, and money market instruments.

Only the types of off-balance-sheet business are listed, and there are no descriptions of the specific operations and investment of off-balance-sheet business. There are two rural commercial banks, namely TJ and JY. Take TJ as an example, in the notes to the financial statements, a list of the off-balance-sheet businesses carried out by the Bank will be introduced to introduce the Bank's off-balance-sheet business categories: one is a risky off-balance-sheet business, which needs to guarantee the customer or assume the customer default risk. The other type is risk-free off-balance-sheet business, such as the settlement agent class. The bank also introduced the specific business carried out by the bank, such as bank acceptance bills, letters of credit, and bank guarantees.

There are 5 banks without special introduction to off-balance sheet business, namely DG, WH, JN, CS and DL.

Third, the responsibilities and authorities of the relevant off-balance-sheet business management institutions or positions.

In the "Corporate Governance " section, the duties and responsibilities of the special committees of the board of directors, the board of supervisors, the special committees of the board of supervisors, and the senior management 
personnel were introduced, but the duties and responsibilities of the specific management organizations of the off-balance sheet activities were not described about 9banks, namely CQ, SH, BJ, GZ, CD, DG, TJ, JN, JY.There were no disclosures on the organizational structure and the responsibilities of each organization. There were three rural commercial banks, namely $\mathrm{WH}, \mathrm{CS}$ and DL.

\subsubsection{Disclosure of Importance}

First, off balance sheet business scale and amount.There are 4 companies that have made detailed disclosure on the scale, amount, classification, sub category amount and scale of off balance sheet business, namely $\mathrm{CQ}, \mathrm{SH}, \mathrm{BJ}$ and $\mathrm{CD}$.

There are only 5 companies that disclose the amount of various off balance sheet businesses, namely GZ, TJ, JN, CS and JY. They disclose the scale and amount of off balance sheet business by category. There are two undisclosed off balance sheet businesses, namely DG and WH. Information users cannot directly access the off balance sheet business scale and amount information.

Second, income from off balance sheet business. The income of off balance sheet business is reflected in the "service fee and commission income". Most rural commercial banks disclose the service fee income. In addition, some rural commercial banks also disclose the proportion, increase, decrease and growth of off balance sheet business income. Except DG and DL didn't make special disclosure on commission and commission income, the other 10 rural commercial banks made detailed disclosure. DG and DL only attach the profit statement of the year in the annual report, and the information users can only obtain the total amount of "Commission and commission income" of the year through the profit statement.

Third, credit risk.Seven rural commercial banks have disclosed the amount that can best represent the maximum credit risk exposure on the balance sheet date without considering the available collateral or other credit enhancement, namely CQ, SH, BJ, GZ, CD, JN and JY. Among them, CQ has also disclosed the credit commitment amount calculated by credit risk weighting, and the risk weight of contingent liabilities and credit commitment varies from $0 \%$ to $100 \%$. There are 5 rural commercial banks not disclosed, namely DG, TJ, WH, DL and CS.All 12 banks have written descriptions of the bank's credit risk management to varying degrees, most of which can be summarized as internal rating method, internal model method and other methods, and gradually establish a unified credit monitoring mechanism for customers.

Fourth, market risk.Market risk mainly includes interest rate risk and exchange rate risk. In addition to DG and $\mathrm{WH}, 10$ of the 12 banks disclosed interest rate risk, exchange rate risk management and risk measurement techniques, including sensitivity analysis, scenario analysis and stress test. Ten rural commercial banks have adopted a unified form to present the book value of assets, liabilities and off balance sheet items of different maturities or currencies, calculate interest rate sensitivity gap and foreign currency exchange rate risk exposure, and conduct sensitivity analysis of interest rate or exchange rate.Taking $\mathrm{BJ}$ as an example, it disclosed the bank's market risk management situation in the way of text description, and sets up the relevant content of "market risk management" in the "risk management" section. In the "notes to financial statements" section, there is a "financial risk management" content, which specifically describes market risk and its management: from the overview, measurement technology and limit setting of market risk, interest rate repricing gap analysis, foreign exchange risk, the disclosure is more specific and detailed, but no special disclosure on off balance sheet business, the content is more scattered, and the information Interest demanders need to select market risk and management of off balance sheet business one by one in relevant sectors.

Fifth, liquidity risk.In addition to DG and WH, 10 of the 12 banks provided qualitative text descriptions on the liquidity risk management, and presented the liquidity risk management structure, management policies and measures; in the form of tables, they conducted liquidity risk management on the prediction of expected future cash flow through the analysis of residual maturity date.

Sixth, operational risk.In addition to DG and WH, 10 of the 12 rural commercial banks explained their operational risk management. This paper mainly describes the measures taken by the bank for operational risk management, but does not give a detailed description of the operational risk and management of off-balance sheet business.Taking CS Agricultural Bank as an example,in the "summary of accounting data and business data" section, it is pointed out that according to the relevant provisions of CBRC, the basic index method is used to measure the operational risk, and the amount of operational risk weighted assets is disclosed, while the amount of off-balance sheet operational risk weighted assets is not separately disclosed.In the section of "all kinds of risks faced by the company and relevant countermeasures" , it is pointed out that the bank has formulated and constantly improved the basic system, management regulations and business operation processes to ensure implementation, strengthen business process control to carry out operational risk management, and has not disclosed the operational risk management of off-balance sheet business.

\section{CONCLUSION}

The results of this paper show that the level of off-balance sheet activities information disclosure varies greatly among the rural commercial banks, among which the top and large-scale rural commercial banks, such as CQ,SH,BJ,GZ,CD, are more fully disclosed, which is convenient for information users to obtain information related to off-balance sheet business, and other rural commercial banks have relatively simple disclosure.As far as the disclosure of various elements is concerned, the timeliness of disclosure is uneven; under the situation of increasingly stringent supervision, the disclosure of authenticity indicators is more adequate; the disclosure level of integrity and importance indicators needs to be improved, especially the variety and specific operation of off-balance-sheet business, and the risk disclosure still needs to be strengthened.

\section{ACKNOWLEDGMENT}

This research was financially supported by the National Social Science Foundation(17GBL004). 


\section{REFERENCES}

[1] Xinhong Guan,Commercial bank information disclosure and market constraint,Accounting Study,2007, (05).

[2] Zhiru Hou, Junjie Chen, Ziliang Wang, Experience in risk management of off-balance sheet business of foreign commercial banks, Bankers, 2017, (1).

[3] Huamao Tian,Bank off-balance sheet business risk management, China Finance, 2015, (1).

[4] China Banking Regulatory Commission,Methods of information disclosure for commercial banks,2007.

[5] China Securities Regulatory Commission, Rules for the compilation and reporting of Corporate Information Disclosure of publicly issued Securities No. 26-Special provisions on Information Disclosure of Commercial Banks, 2014. 